\title{
Commoning in dynamic environments: community-based management of turtle nesting sites on the lower Amazon floodplain
}

\author{
$\underline{\text { Juarez Pezzuti }}^{1}$, Fábio de Castro $^{2}{ }^{2} \underline{\text { David G. McGrath }}^{3}$, Priscila Saikoski Miorando $^{4}, \underline{\text { Roberta Sá Leitão Barboza }}^{5}$ and Fernanda \\ Carneiro Romagnoli ${ }^{6}$
}

\begin{abstract}
Community-based natural resource management (CBNRM) involves a system of local practices designed to regulate access to, and use of, natural resources through rules and norms shared by a set of users. These institutions are usually defined through rational motivations that drive collective action and well-delimited social and spatial boundaries. We discuss the shortcomings of these premises in dynamic ecological systems where the location of resource concentrations is ephemeral. We explore four cases of communitybased management of river turtle nesting sites on the lower Amazon floodplain. Despite the high ecological risks, monitoring costs, and limited material benefits, community residents remain motivated to engage in this collective activity. Based on information from numerous studies carried out over a period of two decades, we discuss how motivation to develop CBNRMs has changed over time and space and how intercommunity linkages have contributed to the endurance of this local institution.
\end{abstract}

Key Words: Amazon; common pool resources; conservation; hydrological cycle; turtles

\section{INTRODUCTION}

Community-based natural resource management (CBNRM) consists of local practices that regulate access to, and use of, natural resources through rules and norms that are shared by a set of users (Berkes and Folke 1998, Berkes 2004, Child and Barnes 2010). These institutions are built on social and ecological pillars. The former includes capabilities and motivations to engage in collective action. Cultural norms and social organization can facilitate local users' willingness, commitment, and skill in collaboration (Ruiz-Mallen et al. 2015), while broader contextual factors, such as policies, financial support, and conflicts with external actors, can trigger interest in engaging in collective efforts to manage local resources (Seixas and Davy 2008). The latter includes biological and physical processes that influence the managed system, ranging from attributes of the resource such as mobility (Schlager and Ostrom 1992) to predictability and ecosystem vulnerability. The degree of fit between regulated practices and ecological context is a key factor influencing the performance of these institutions (Ostrom et al. 1999, Berkes et al. 2000).

As a social-ecological system, CBNRMs are usually analyzed according to social and ecological boundaries and the underlying motivations driving people to engage in this enterprise. However, CBNRMs are socially constructed institutions characterized by porous and flexible social and ecological boundaries (de Castro 2012), and they combine multiple and changing motivations (Cleaver 2002). We argue that cross-community connections and intangible values are particularly relevant in CBNRMs that are facing rapid social-ecological changes. Assessing users' motivations to build CBNRMs and their respective performance requires analysis not only of commoners' direct gains and the sustainability of the managed ecosystem and resource, but also social benefits and effects beyond the managed systems and the commoners.

Based on the analysis of four collective efforts involving four turtle nesting sites (locally denominated tabuleiros) on the Amazonian floodplain, we discuss some important shortcomings of utilitarian, place-specific perspectives in CBNRM research. Our analysis focuses on the process driving deliberately nonmaterial goals of this management system and the intercommunity connections that seek to cope with the challenges of a highly dynamic and unpredictable ecological system.

While emergence and performance of local governance systems is usually measured through tangible benefits (e.g., conservation, livelihood security) within a particular physical space (managed area) and social (user group) boundaries (Ostrom 1990), the highly restrictive ruling system of turtle nesting sites cannot be explained by tangible gains, and their fast changing nature cannot be analyzed through well-defined boundaries. Such a utilitarian and boundaries-oriented perspective on CBNRMs fails to capture the benefits/values of initiatives that generate outcomes and benefits beyond the managed system. Under high ecological vulnerability, costly monitoring systems, and restrictive conditions to a valuable food item, our goal is to understand what motivations are driving community residents to engage in this management system and the outcomes of their efforts.

We propose a broader analytical perspective that takes nonmaterial motivations not as side-effects of cultural processes but as conscious decisions based on socio-cultural values. In addition, we develop an intercommunity perspective in order to understand the mechanisms driving the emergence and development of these local governance systems. We argue that the commoners and the managed resource may not be the most

${ }^{1}$ Centre for Advanced Amazon Studies, University of Pará, Belém (PA), Brazil, ${ }^{2}$ Centre for Latin American Studies and Documentation (CEDLA), University of Amsterdam, The Netherlands, ${ }^{3}$ University of Western Para (UFOPA), Santarém, PA, Brazil and Earth Innovation Institute, San Francisco, CA, USA, ${ }^{4}$ University of Western Para, Campus Oriximiná, Pará, Brazil, ${ }^{5}$ ESAC (Grupo de Estudos Socioambientais Costeiros), Universidade Federal do Pará (UFPA)/ Campus Bragança, Bragança, PA, Brazil, ${ }^{6}$ Rural University of Pará, Campus Capitão Poço, Pará, Brazil 
appropriate social and spatial scales to address sustainability of this particular resource and ecosystem over the long term. Rather, they are key building blocks of a regional arrangement of CBNRMs upon which knowledge, motivation, and value are built and transferred to other initiatives.

\section{METHODS}

The Amazon floodplain (várzea) is a highly productive and dynamic ecological system which has supported large human populations since the pre-Colombian period (Roosevelt et al. 1991, Goulding et al. 1996). Continuous input of nutrient-rich sediments from the Andes region and carried out through the river channels provides conditions for landscape change and development of abundant and diverse natural resources (Irion 1984, Denevan 1992, Junk 1997). The flood pulse is a cyclical annual process of flood and low water seasons that provides nutrient input and habitat diversity in lake systems for fish (Junk 1997). Despite variations in intensity or pace of the flood and low water seasons, the pattern of change in size, shape, and depth of river channels and lakes throughout the year is relatively predictable over time. In contrast, linear process provides unidirectional landscape changes through gradual sedimentation and (sometimes abrupt) erosion of sandy beaches and riverbanks. This dynamic process leads to continuous changes in boundaries and ecological vulnerabilities such as sedimentation, erosion, and bank collapse along rivers, side channels, and lakes.

This dynamic system provides opportunities and constraints for human occupation and natural resource use. In the municipality of Santarém, which has approximately 280,000 inhabitants, $15 \%$ of the population lives in floodplain communities. These communities range from a dozen to more than 100 households. They have strong family ties and are organized in associations and socially structured with collective infrastructure and services such as churches, schools, and health and community centers. Informal social relations between communities facilitate exchange of products, services, and information among local residents. Residents rely on both aquatic and terrestrial resources for their livelihoods. Diversified production systems, organized around household structure, combine fish, game, small animal husbandry, and perennial and annual crops such as corn, manioc, and beans, are the keystone of their subsistence and income (de Castro 2012).

In particular, the sedimentation process along the river channels and lake margins may lead to the emergence of beaches that are used by birds and turtles for reproduction. These nesting sites are usually temporary because they are prone to erode as part of the natural geomorphological dynamics. Turtles and their eggs are an important item in the local diet, and for some residents, they are also part of their cash economy. Three turtle species (Fig. 1) nest in the lower Amazon during the low water season (AugustDecember). Tracajá (Podocnemis unifilis) nests along river, channel, and lake margins, while pitiú ( $P$. sextuberculata) and tartaruga ( $P$. expansa) are more selective and nest only on sandy river beaches. According to Barboza (2012), turtle and egg consumption is relatively high in the region. Tracajá and pitiú are the favorite species for consumption; however, the latter is avoided during illness or pregnancy. Tartarugas are the least preferred species in the local diet and are often used as local medicine and cosmetics (Alves and Rosa 2007, Pezzuti et al. 2010). Although the sale of turtles is illegal, turtles, usually females, due to their larger size (twice as large as males), are traded in illegal markets. The pitiu is the smallest species (average weight $3 \mathrm{~kg}$ ) but is the most commonly sold (US\$10-14/individual in the local market) due to their higher abundance. The tracajá reaches up to $8 \mathrm{~kg}$ and is sold at US\$17-25/individual. The tartaruga is the largest and most valuable species, reaching $40 \mathrm{~kg}$, and sells for US\$71-110/ individual.

Fig. 1. Three turtle species that nest in the lower Amazon: (A) tartaruga (Podocnemis expansa); (B) pitiú (P. sextuberculata); (C) tracajá (P. unifilis).

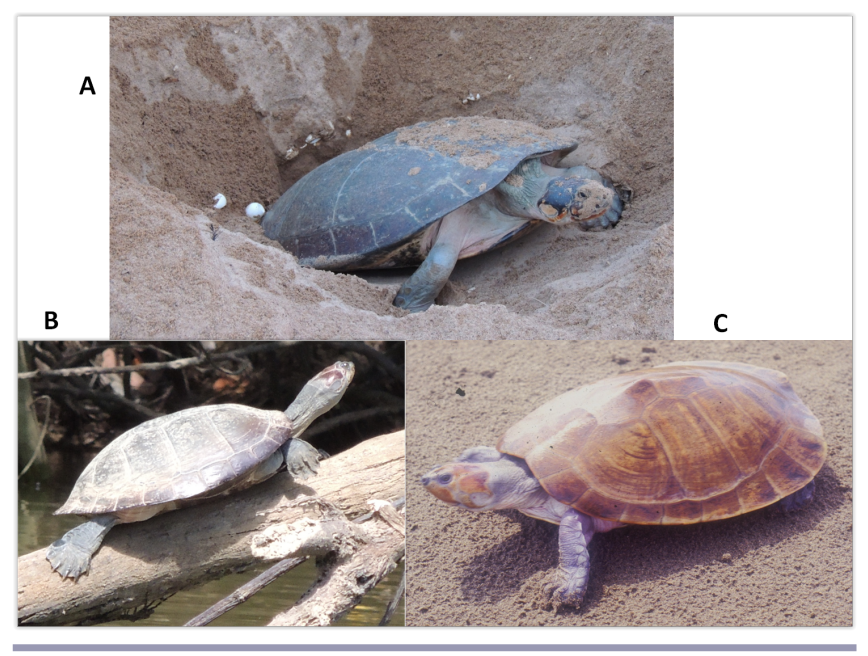

The lower Amazon region is well-known for another CBNRMcollective fishing agreements - that regulate fishing in community lakes by both outside commercial fishers and local residents (McGrath et al. 1993). Largely influenced by Catholic Church programs inspired by liberation theology, fishing agreements are based on documents drafted by community residents that present rules regulating the use of local fish resources. The rules negotiated in community meetings are ratified by majority vote (de Castro and McGrath 2003). While fishing agreements are well described in the academic literature (see e.g., McGrath et al. 1993, 2008, de Castro and McGrath 2003, Castello et al. 2009), community-based management of turtle nesting sites has received little attention from CBNRM scholars. The relative invisibility of this local institution may be related to less conspicuous motivations and institutional arrangements. In contrast to the concern for income and subsistence security driving management of lake fisheries (de Castro 2000), the management of turtle nesting sites has emerged in the region as a way to protect nesting females and their offspring. Increased concern about the depletion of turtles has motivated local communities to engage in developing CBNRMs since the 1970s.

Community-based natural resource management initiatives for turtle nesting sites involve monitoring and enforcing bans on turtle hunting and egg harvesting within protected areas defined by the community. This requires significant investments of time and energy by community members to control human and animal predation. These costs may not be compensated by material benefits as communities must refrain from harvesting turtles and eggs in protected areas. At the same time, female turtles and 
Fig. 2. Map of the studied area showing the communities with their respective protected tabuleiros: Ilha de São Miguel (ISM), Costa do Aritapera (CDA), Água Preta (AGP), and Aracampina (ARA).

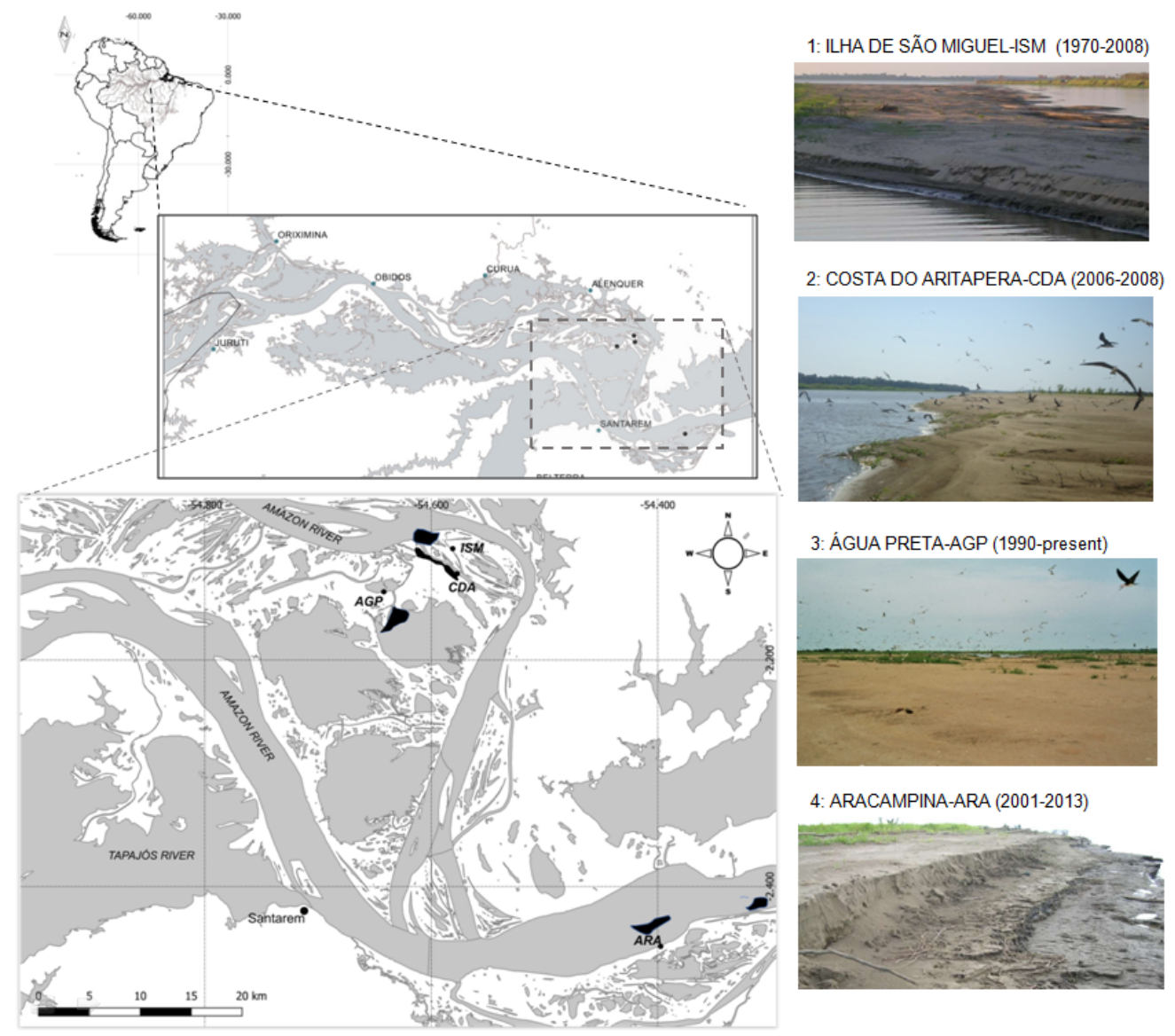

hatchlings migrate elsewhere, and these areas may last only a few years due to year-to-year changes in local floodplain geomorphology. A more fluid arrangement for the management of local turtle nesting sites contrasts with the formal structure of the fishing agreements. Regulations on the turtle nesting sites occasionally appear in fishing agreements. de Castro and McGrath (2003) noted that approximately $25 \%$ of the 77 fishing agreements analyzed in the lower Amazon referred to turtle and egg hunting. In practice, however, these restrictions were largely ignored, and in some cases, there were no community restrictions on exploiting turtle and eggs.

We present case studies of CBNRM initiatives involving tabuleiros in four communities (Fig. 2). Ilha de São Miguel(ISM), with approximately 55 families, is well-known in the region for its successful lake management system (McGrath et al. 1993, de Castro and McGrath 2003, de Castro 2012), which combines subsistence fishing for most species with seasonal commercial exploitation of catfish and pirarucu (Arapaima spp.) during the government-defined pirarucu fishing season, 1 June to 30 November. Água Preta (AGP), with approximately 60 families, is located on the shores of Água Preta lake, connected to one of the largest lakes in the region (Itarim). Aracampina (ARA), on the island of Ituqui, has approximately 60 households settled along a narrow natural levee between the main river channel and an extensive lake system occupying the interior of Ituqui Island. Costa do Aritapera (CDA), with 47 households distributed along the levee of a side channel linking Itarim lake to the Amazon River, is midway between Ilha de São Miguel and Água Preta. This community is well-known for poaching fish and turtles in lakes managed by neighboring communities, especially ISM, which results in constant intercommunity tension and conflict.

This paper developed out of discussions among the coauthors, all of whom have undertaken CBNRM research in one or more of the four communities analyzed in this paper. The data sets combine findings from numerous indepth research projects (including three doctoral dissertations) spanning more than two decades (1991-2014) as part of a long-term research network that includes universities and local NGOs. ${ }^{[1]}$ The analysis was based on the combination of interviews with key leaders and other members of communities that are protecting turtle nesting sites, observation of management activities and landscape change over a series of reproductive seasons and hydrological cycles, and documentation of ethnoecological information on turtle populations and reproductive behavior. In addition, the 
coauthors were involved in participatory research with local NGOs, universities, and governmental agencies, in which interactions between these institutions and community residents regarding the management of tabuleiros could be observed. Finally, official data on the number of turtle nests in ISM and AGP were made available for two species- $P$. expansa and $P$. sextuberculata - by the Brazilian Agency for the Environment and Natural Renewable Resources (IBAMA). Inconsistencies found in these data were cross-checked with our field notes and with interviews with residents.

Although the coauthors have been involved in research projects at different locations, scales and time periods, they have collaborated in different periods. DM has coordinated several CBNRM projects in the region over the last two decades, has carried out multiple interviews with local residents, and has been directly involved in the development of participatory projects to strengthen CBNRM in all four communities. FdC carried out ethnographic analyses of CBNRMs in two communities, ISM and ARA, which involved monthly visits between 1991 and 1993. Subsequently, during intermittent follow-up visits, information on the history of the turtle nesting sites in ISM, their management structure, and local perceptions of the initiative was collected through informal interviews with local residents and direct observation (see de Castro 2000). Subsequently, between 2007 and 2008, RB carried out ethnoecological research on river turtles, and monitored use and consumption of aquatic resources (including river turtles) in ISM, CDA, and AGP (see Barboza 2012). JP and PM were involved in community monitoring of turtles and caimans in ISM, CDA, and AGP between 2006 and 2008. This included assessment of turtle populations to evaluate abundance, size, and sex structure, using local fishing equipment, skills, and knowledge, as well as training local community groups to map and monitor nests of eggs laid each year in their respective community protected areas (Pezzuti et al. 2010, Pignati et al. 2013). Finally, FR investigated the social organization of AGP related to the management of local aquatic wildlife between 2012 and 2014, using participatory observation and interviews with key informants (Romagnoli 2016).

Due to the different academic backgrounds and methodological approaches employed in these different studies, the data set is unbalanced in providing quantitative and ethnographic evidence. For example, we present a limited number of quotes because most of the researchers preferred to write field notes rather than record and transcribe interviews. Notwithstanding these shortcomings, the combination of detailed social and ecological data available for each community, including longitudinal data, indepth community research, and extensive investigation of the socialecological context, has resulted in a solid data set for addressing intercommunity issues related to CBNRMs in the region. In this respect, the knowledge exchange among coauthors facilitated scaling up from individual community processes to exploring intercommunity connections among CBNRMs in the region.

\section{RESULTS}

The four experiences described in the following sections are cases where community members transformed commoning local turtle nesting sites into commons by taking collective control and implementing rules for access, use, monitoring, and enforcement. The emergence of new sandbanks close to a community triggers residents' attention to the availability of a new resource concentration. Their level of social organization, perception of the resource, and relations with other actors influence their organization and commitment to protecting this ephemeral habitat. The factors driving the emergence, development, and in some cases, decline of turtle management practices vary among communities with ecological transformations, on the one hand, and leadership and intracommunity and intercommunity social interactions, on the other, playing key roles.

\section{Ilha de São Miguel}

The protected tabuleiro on ISM was well-known in the region, and to the best of our knowledge, was the first local initiative of turtle nesting site conservation in the Amazon Basin. According to older residents, ${ }^{[2]}$ it started in the 1970 s after a beach emerged on the northwest side of the island (locally called Prainha), about $45 \mathrm{~min}$ by foot from the community center (Fig. 2). Management began with members of a household who settled and farmed near the beach. The gradual expansion of the sandbank ${ }^{[3]}$ was followed by an increase in the number of nesting turtles, which attracted egg hunters. In order to minimize crop damage associated with increased egg hunting, the local farmers decided to ban this activity in the area and create a protected area. Initially, the "private" arrangement of this local regulation caused resentment among community residents who claimed that this conservationist measure was used to appropriate a valuable communal area and resource. As the farmers gradually quit their crop activities on the beach and shifted focus to the turtle nesting site, local residents recognized the importance of the initiative and gave full support to the protected area.

Despite community support, local residents still referred to the managed site as "the tabuleiro of Mr. Jose's", ${ }^{4]}$ which indicated its household-based management structure. The tabuleiro, along with their lake management system, reinforced the community's image as a role model for innovative conservation-oriented CBNRMs in the region. In the early 1990s, during our first field visits, local residents emphasized with pride the relevance of their management practice and invited us to visit the site during the nesting season. Between 1991 and 1994, we observed their management practices, which were based mainly on their local knowledge, such as nest counting, spreading poisoned meat or fish and spraying insecticide to control natural predators (e.g., ants and lizards), and regular trimming of the beach vegetation "...to let the sand dry and avoid mud accumulation, which may spoil the nesting process or damage the nests," as explained by one family member. Finally, the local residents monitored the nesting site and surrounding area, and enforced the ban on egg and turtle hunting. Enforcement measures involved regular patrols on the beach and surrounding areas, and occasional sanctions, such as gear confiscation from violators.

Despite some gaps and irregularity observed in data registration, ${ }^{[5]}$ the logbook shows a clear trend of growth in the number of nests of pitiú and tartaruga (Table 1). This rapid development attracted the attention of the Brazilian Institute for the Environment (IBAMA). In 1990, it initiated an informal partnership with the family by providing them with material and a small amount of financial support, and in 2004, it registered the protected tabuleiro as an official protected zone. Governmental support, however, was limited to the occasional supply of fuel 
Table 1. Number of nests counted by local residents in two communities between 1990 and 2003 (quality of official data is limited by variation in counting effort between different seasons).

\begin{tabular}{|c|c|c|c|c|}
\hline \multirow[b]{2}{*}{ Year } & \multicolumn{2}{|c|}{ Agua preta } & \multicolumn{2}{|c|}{ São Miguel } \\
\hline & Podocnemis unifilis & P. sextuberculata & P. sextuberculata & P. expansa \\
\hline 1990 & - & - & 5064 & 3 \\
\hline 1991 & - & - & 6979 & 0 \\
\hline 1992 & - & - & 8873 & 14 \\
\hline 1993 & 2104 & 804 & 10,288 & 23 \\
\hline 1994 & - & 1601 & 9542 & 34 \\
\hline 1995 & 250 & 200 & 10,558 & 11 \\
\hline 1996 & 680 & 604 & 11,904 & 80 \\
\hline 1997 & 782 & 636 & 12,084 & 144 \\
\hline 1998 & 389 & 68 & 10,524 & 67 \\
\hline 1999 & 2707 & 1888 & 9638 & 169 \\
\hline 2000 & 4763 & 1822 & 10,101 & 242 \\
\hline 2001 & 4241 & 2961 & 9841 & 4 \\
\hline 2002 & 6350 & 5635 & 7603 & - \\
\hline 2003 & 6120 & 5200 & 9062 & 837 \\
\hline
\end{tabular}

and food for patrols when funding and staff were available. Community residents also became more active in their support. For example, they organized a collective harvest of high-priced lake fish, pirarucu (Arapaima spp.), to raise funds to support the patrolling of the tabuleiro during the nesting season.

The successful ecological and social performance of the tabuleiro was challenged by natural ecological change. In 2004, the beach started to erode and split into four sandbanks of different sizes. In the following year, the beach completely disappeared, and most turtles moved to a nearby beach nesting area, which washed away two years later. Since 2009, there have been no more large beaches in the community area with significant numbers of nesting females. However, one coauthor was contacted in 2010 by representatives of Ilha do Meio community, which is located upstream from ISM, due the sudden appearance of a large group of nesting $P$. expansa on a beach situated within that community's territory. The representatives asked for help in obtaining institutional support and to request formal reconnaissance of the nesting site by IBAMA. Both communities, ISM and Ilha do Meio, are absolutely certain that these females were the ones that previously nested in the ISM area.

In sum, what began as the initiative of a single household motivated by economic goals - protection of the bean fieldtransitioned into a community-based enterprise motivated by an explicit conservation goal and pride, integrated with other collective management activities (community-based lake fisheries management). Despite the abrupt disappearance of the nesting beach, the community scope, knowledge, and inspiration spilled over to neighboring communities facing similar challenges and opportunities (Fig. 3). Strong commitment and leadership by one resident and his family were instrumental in not only developing the management system and scaling up to the community level, but also in disseminating the idea and values attached to this CBNRM to other communities through personal assistance and knowledge exchange, as described in the following sections.

\section{Água Preta}

As with ISM, a sandbank emerged along the shores of Itarim lake, close to Água Preta, in the 1980s and gradually expanded into the lake (Fig. 2). In contrast to ISM, however, the area was used mainly by tracajá females, and the initiative was a collective effort from the start. According to a resident, the rapid increase in nest numbers during reproductive seasons attracted people from the region to hunt eggs and adults: "the community realized that (tracajá) were nesting...people come from other places to collect [eggs]." A group of elders brought the issue to a community meeting in 1990, in which the residents voted to establish a community protected area. According to their agreement, the entire tabuleiro and surrounding waterbodies were designated as a reserve, where no aquatic resources (including fish) could be exploited for either consumption or sale. As one of the oldest residents explained, "It was the local residents who wanted to create the reserve because there were a lot of mallards, birds, and tracajá."

Fig. 3. Scheme showing how knowledge, values, and motivations to protect a tabuleiro have traveled across communities.

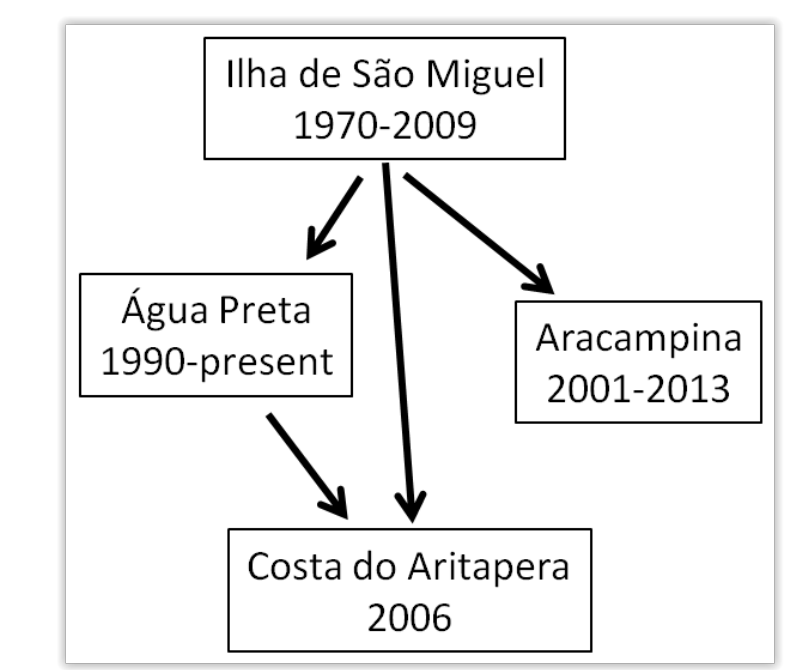


Inspiration and support from ISM residents were instrumental to the design of community management activities in AGP, as illustrated by one local resident's comment: "It started from the successful management in ISM and they tried to do it here because their (turtle population) was almost over." The resident in charge of the protected tabuleiro in ISM was invited to visit the community reserve and give instructions to AGP residents on management practices to reduce nest losses, carry out daily monitoring (nest counting and marking), and organize a patrolling system. This knowledge transfer was particularly useful for organizing patrol teams at night, usually on horses, with women providing meals, as explained by one resident: "...we monitored the area ourselves. Every day, three, four of us. We even carried weapons."

In 1991, due to intense egg poaching, the community followed the steps of ISM and requested support from IBAMA. According to the logbook, the performance of the reserve in AGP was less effective than that in ISM. Between 1991 and 1994, there was an increase nesting by the three species, followed by a decrease and fluctuation thereafter. Although part of this pattern can be related to inconsistent data collection, informants confirmed the challenging task of controlling both internal and external poaching: "...many follow and many do not follow the agreement. There were many people against and many in favor; "the number of turtles...dropped because they are pressured from everywhere...if there was not this issue of collect to sell, this would be the richest place." In 2006, university researchers and a local NGO (including three coauthors) joined with the community to strengthen the management of the tabuleiro. They were involved in participatory research, technical assistance for nest monitoring, and funding for community patrols. However, unlike ISM, community residents lacked a successful lake management system to reinforce their commitment to the protected nesting site.

According to the residents, limited patrolling and a lack of sanctioning mechanisms were major constraints in their efforts to control poachers. The lack of formal recognition of their reserve by IBAMA limited the ability of residents to use legal procedures to punish violators, as illustrated by the frustration of one informant: "The reserve is a mess...the community cannot exploit...violators pay fine but do not go to jail... the fine does not go to the community, it goes to Federal Police and IBAMA." In addition, perhaps more problematic, kinship ties between patrolling members and poachers made punishment a socially sensitive task. Discontinuity in funding, which led to the suspension of most management activities, added to the gradual decline of community conservation efforts. As with ISM, fuel, a tent, and occasional support for patrols was provided, but financial and institutional support remained limited. ${ }^{[6]}$

To date, the challenges for the management of the tabuleiro remain. Access to the nesting site was fenced in order to protect it from cattle and dogs; however, the low water period facilitates access to the nesting site by foot, horseback, and motorcycle through the dry river channels. Easy access, combined with limited commitment from the residents, has led to the intensification of poaching of females and eggs.

\section{Aracampina}

In 2001, residents of Aracampina decided to protect a sandbank (Praia Grande) that emerged $3 \mathrm{~km}$ downstream from the community. The area was identified as a nesting site for tartaruga and pitiú. Community residents were supported by ISM, IBAMA, and a local NGO. The latter, which had been developing a participatory research project in the community since the 1990s, organized a visit by ARA residents to the turtle nesting site in ISM. During that visit, 2000 hatchlings were donated to be released on the turtle nesting site in ARA as part of the official launch of their management of their tabuleiro. The Brazilian Agency for the Environment and Natural Renewable Resources, which was more familiar with the community-based management of tabuleiros, supported the initiative with fuel during the first six months to carry out patrols. In the following year, the community added another beach (Praia dos Coelho), located $7 \mathrm{~km}$ downstream from the community (note two nesting sites downstream from ARA in Fig. 2).

Between 2003 and 2006, the community association received small grants from the government and the NGO to implement several community-based initiatives in which the tabuleiro management was included. ${ }^{[7]}$ Round-the-clock patrols were organized during the nesting season through a team rotation scheme. However, the long distance from the community discouraged residents from carrying out regular patrols. This was especially problematic for the nesting site located on the more distant beach (Praia dos Coelho), where, according to the residents, only two patrols of the tabuleiro were undertaken in 2003.

Similar to other communities, discontinuity in funding for fuel as well as lack of legal support for protecting the tabuleiro were the main short-term constraints to the effectiveness of ARA's initiative. In addition to human impacts, the area was vulnerable to erosion, and by 2011, the beach had completely disappeared. Residents organized the transfer of nests to a closer site with similar ecological conditions that were favorable for turtle nesting. At the closer beach (Praia Grande), the number of nests increased over time. However, the constant traffic of river boats and canoes along the beach contributed to bank erosion and nest loss, and limited the access of nesting females to the higher nesting sites. Collective efforts were taken to restore eroded slopes along the beach in hopes of helping nesting females climb to higher spots. The community was actively engaged in the CBNRM until 2008, when most of the sandbank eroded away during the flood season. The egg hunting ban in the remaining nesting area was still active until 2013 when several tartaruga females were still nesting in the area. However, in the following year, the site was completely washed away by the river.

\section{Costa do Aritapera}

The most recent initiative for protecting a turtle nesting site observed in the region was in Costa do Aritapera, located across the channel from ISM (Fig. 2). From 2004 onward, community residents, especially fishermen, observed a rapid increase in the number of pitiú and tracajá nests on the beach along the community. This event coincided with the beginning of the erosion of the beach in ISM, and CDA residents explained the increase in nests as an outcome of the gradual displacement of turtles from the ISM tabuleiro located on other side of the channel.

In contrast to the other three cases, the management of the turtle nesting site in CDA did not emerge as an endogenous process. Residents were motivated by a research project initiated in 2006 
Table 2. Characteristics of the turtle management initiatives carried out by four communities in the lower Amazon floodplains.

\begin{tabular}{|c|c|c|c|c|}
\hline & Ilha de São Miguel & Água Preta & Aracampina & Costa do Aritapera \\
\hline Start & 1971 & 1990 & 2000 & 2006 \\
\hline End & 2009 & In progress & 2008 & 2008 \\
\hline Main species & $\begin{array}{l}\text { tartaruga } \\
\text { pitiú }\end{array}$ & tracajá & $\begin{array}{l}\text { tartaruga } \\
\text { pitiú }\end{array}$ & pitiú \\
\hline Nesting habitat & River beach & Lake sandbank & River beach & River beach \\
\hline Management practices & $\begin{array}{c}\text { Trimming } \\
\text { Insecticides spray } \\
\text { Patrolling }\end{array}$ & $\begin{array}{l}\text { Fencing the area } \\
\text { Patrolling }\end{array}$ & $\begin{array}{c}\text { Transferring of nests } \\
\text { Sandbank restoration } \\
\text { Patrolling }\end{array}$ & Transferring of nests \\
\hline Challenges & $\begin{array}{l}\text { Limited official support } \\
\text { Internal conflicts } \\
\text { Erosion and landslides }\end{array}$ & $\begin{array}{l}\text { Limited official support } \\
\text { Generational conflict } \\
\text { Nest predation by dogs } \\
\text { Nest destruction by cattle }\end{array}$ & $\begin{array}{l}\text { Limited official support } \\
\text { Erosion and landslides }\end{array}$ & $\begin{array}{l}\text { Limited official support } \\
\text { Low commitment } \\
\text { Nest predation by dogs }\end{array}$ \\
\hline Key limiting factor & Ecological: erosion & Social: internal conflicts & Ecological: erosion & Social: internal conflicts \\
\hline
\end{tabular}

which aimed to strengthen local institutional capacity for natural resource management and minimize the conflict between ISM and CDA residents. ${ }^{[8]}$ Costa do Aritapera is known in the region as the home of people who ignore management rules in lakes of nearby communities, such as fishing in lake reserves and catching pitiús to sell in the nearby city of Santarém and neighboring communities. In order to increase local commitment to the initiative, the management model combined a hybrid system. One part of the nesting site — visited mainly by pitiú — was designated as a no-take zone, while a another part located in front of the community was open for subsistence egg hunting. Ironically, local efforts to control egg hunting were challenged by high levels of natural nest predation in the protected area, primarily by domestic dogs and secondarily by birds. Community leaders discussed possible ways to solve the problem, such as the transfer of nests to a fenced area. However, although the beach area was ecologically stable, the limited interest of community residents discouraged efforts to maintain it as a protected area, and two years later, the initiative was abandoned.

\section{DISCUSSION}

The four CBNRMs represent points on a continuum in which ISM and CDA represent the two endpoints. On one end, the ISM initiative was initially developed by one family with no external support and later developed into a community commitment with successful conservation outcomes that lasted for more than two decades until it was disrupted by changes in river geomorphology. On the other end of the continuum, the CDA initiative was proposed by outside actors, was supported by external funding, and was short-lived due to limitations in social organizational capacity. The two intermediate cases-AGP and ARA-had mixed results (Table 2). The former is the only case in which a turtle nesting site is still functional; however, it is facing rapid social and environmental change. The latter case also faced challenges in monitoring due to the distance from the community, and was eventually eroded away.

Over three decades, numerous communities have developed CBNRMs to protect the same natural resource, whose nesting sites have shifted around as a result of natural geomorphological changes in the floodplain system. During this period, a genuine bottom-up initiative in ISM inspired other communities to develop similar initiatives that were supported (or promoted in the case of CDA) by external actors. In this process, local knowledge, management skills, social learning, and emotional attachment to turtles developed and were exchanged between communities. The intercommunity linkages among communitymanaged turtle nesting sites shed some light on socio-cultural factors driving local residents to engage in "irrational" conservation behavior and on social-ecological mechanisms supporting the transfer of this practice between communities. The former addresses the motivations driving community residents to engage in this endeavor with such high social and environmental costs and risks. The latter addresses the role of the ecological dynamics of local systems that require stretching the boundaries of the locally managed resource to a regional scale.

\section{Beyond material motivations}

As observed in other regions of the Amazon (Pezzuti and Vogt 1999, Fachin-Terán et al. 2003, Camillo et al. 2012), the community-based management of turtle nesting sites we have analyzed involves banning the collection of turtles and eggs within community-designated protected areas. This restriction constitutes a major onus for the residents because turtle meat and eggs have an important cultural role in the region. Amazonian riverine societies consider these resources to be delicacies to be appreciated on special occasions and during only one or two months of the year (Smith 1974, Mittermeier 1975, Johns 1987, Murrieta 1998, Rebêlo and Pezzuti 2000, Pezzuti et al. 2010, Alves et al. 2012). They have been part of the local diet in the region since precolonial times (Carvajal 1543, Silva-Coutinho 1868, Bates 1892, Pereira 1954, Johns 1987) and are highly valued as a special food item to diversify the residents' fish-based diet (Murrieta 1998, Rebêlo and Pezzuti 2000, McGrath et al. 2008, Barboza 2012). In a social-ecological system strongly regulated by seasonal changes, turtle nesting periods are ecological markers of the abundance of the dry season, when adults, elders, and children comb the shores of nearby rivers, lakes, and channels in search of fresh nests and tracks of nesting females. Murrieta (1998) described this event as an emotional trigger among local residents.

Intangible values, however, are not disconnected from other motivations. The ban on egg hunting in ISM started as the initiative of a family seeking to protect their bean crop from cattle. Later, it turned into a community endeavor to protect turtles, 
which fostered the development of a sense of community solidarity and pride regarding their increasingly abundant turtle population. This shift in motivation was reinforced by the material gains from the lake fisheries management system in which the highly productive subsistence fishery provided food security, while the seasonal sale of the high-value pirarucu provided an important source of seasonal income (de Castro 2000). Together, the overlapping management systems supported the development of a community identity characterized by its capacity to collectively address local socio-environmental challenges. To outsiders, the community projected an image of social cohesion, resource abundance, and effectiveness as stewards of nature.

The ISM case shows how strong social capital and the availability of economic alternatives were crucial in supporting intangible values in the face of high incentives to exploit their resources for short-term gain. In contrast to ISM, the protected tabuleiros in AGP and ARA were driven by intangible values from the start because they involved restrictions on use and high monitoring costs with no expected material gains. However, the high commercial value of turtle in illegal markets and its special value in the local diet are strong incentives in both communities because they both face limited economic alternatives and less social cohesion than ISM. As a result, despite the external financial, political, and technical support from government agencies, NGOs, university researchers, and the ISM leaders, motivation to engage in management of both lake fisheries and turtle nesting sites remained limited to a small number of residents. These challenges, however, did not discourage local leaders who were committed to managing local tabuleiros. In ARA, both sites were protected until they eventually eroded away. In AGP, the initiative is still active.

Costa do Aritapera is, perhaps, the only case that follows the rational logic of material incentives. The fact that many residents regularly poached fish and turtles from other communities posed a major challenge to compliance with the rules of their own community. Despite strong external support, flexible institutions/ rules (partly open for subsistence use), and less costly monitoring (the protected area is located in front of the community), incentives for short-term economic benefits remained high and resistance to temptation low. As a result, the protected tabuleiro in CDA lasted only two seasons, despite the relative ecological stability of the site. It is no surprise that the management of the tabuleiro in CDA was short-lived because this initiative was promoted mainly by external actors. Endogenous motivations are fundamental to supporting local management because they are derived from users' concerns and values regarding the managed resource and pride in their accomplishment when they are successful (Ruiz-Mallen et al. 2015).

Regardless of the level of performance, the four cases show how the interplay between material and nonmaterial motivations results in different outcomes according to the characteristics of each community. The overt conservation goal driving the tabuleiro management contrasts with other management initiatives driven by intangible values that have been described in the CBNRM literature, such as sacred groves, where conservation is an epiphenomenal outcome (Gadgil and Vartak 1976, Chandrakanth et al. 2004, Ormsby and Bhagwat 2010), and is usually associated with low-impact lifestyles, low population density, and limited technology (Redford and Stearman 1993, Hames 2007). The management of turtle nesting sites combines both a conscious problem-solving strategy to promote conservation-but not necessarily to generate material benefits-grounded in community ethics and an emotional connection with this group of species.

\section{Beyond community boundaries}

While emotional motivations and social returns seem to explain collective efforts to protect species under highly vulnerable conditions, intercommunity linkages observed between local management systems shed some light on how social learning and community ethics evolve over time and travel over space. The analysis of the performance of community-based management of turtle nesting sites based on outcomes within community boundaries does not capture cross-boundary mechanisms that help build resilience in a high-risk environment. Knowledge accumulated and values shaped through the experience of conserving turtle nesting sites in ISM did not disappear with the erosion of the nesting beach. The experience reinforced the community members' commitment to managing other local resources (e.g., community lakes) and inspired members of other communities to replicate approaches. The analysis of the linkages between the four cases reveals a broader socio-environmental process for coping with complex landscape changes in which local leadership and intercommunity interactions play a key role.

The ephemeral condition of turtle nesting sites poses major challenges for community efforts to build resilient management systems. Although the resource unit (turtle) can be managed due to its relatively consistent migratory cycles and nesting behavior, because of the biophysical dynamics of the floodplain, turtle nesting sites are ephemeral, lasting from a few to many years. Communities may lose complete control of their managed resource when breeding females move to nesting areas beyond the community boundaries. Ilha de São Miguel is a case in point, where strong social capital and successful performance over decades was challenged by the complete erosion of the site in a few years. Therefore, to cope with high-risk environments, social organizational capacity must extend beyond individual community boundaries.

When nesting female groups shift their nesting areas out of community territories, as observed in the ISM case, it implies that managed turtle nesting sites "move" between communities and beyond the control (and potential use) of the original community. Despite the fact that this represents a continuity in conservation and management practices directed to the same resource pool, it challenges the principles of physical and social boundaries often described as necessary ingredients of successful CBNRMs. As argued by Cox et al. (2010), boundaries may not necessarily be well-defined if congruence between users and resource boundaries is met. While contextual factors at the community level lead to different levels of performance at each site, intercommunity connections help in coping with regional ecological pressures. In the case of turtle nesting sites, characterized by social and ecological permeability, close attention should be paid to how these social and ecological linkages are shaped.

Since the seminal work of Netting (1976), analysis of the commons has focused on the interplay between local social and 
ecological processes (see Schlager and Ostrom 1992, Berkes et al. 2000, Berkes et al. 2000). More recent work shows that CBNRMs are part of a multiscaled process that crosses community interactions and landscape units (Cash et al. 2006). Although this literature has been instrumental in linking local and broader institutional arrangements and processes (see Berkes 2006, Sattler et al. 2016), horizontal linkages between communities within a given landscape have received less attention. In this article, we highlight how scaling up community-based management to regional levels may enhance social-ecological resilience on the floodplain. According to residents' perceptions, female turtles move to new sites in response to the erosion of their existing nesting site. The mobility of females to newly established nesting sites was addressed by transferring knowledge from previous experiences to new sites. As observed in other regions, leadership can stimulate collective behavior (Seixas and Davy 2008, Delgano-Serrano et al. 2017) and foster the construction of social networks (Folke et al. 2005, Bodin and Crona 2008). In particular, the ISM residents who initiated the management of the first turtle nesting site in the region played a crucial role by sharing their experience with leaders in neighboring communities and inspiring them to undertake their own initiatives. More recently, interaction with researchers and practitioners has led to a more systematic citizen science perspective. Intercommunity management linkages seem to have major relevance for regional conservation strategies, particularly in social-ecological systems characterized by numerous communities scattered over a dynamic landscape and involving highly mobile animal resources.

\section{CONCLUSION}

We address four experiences in developing commons with different conditions, motivations, and connections. The methodological approach taken here included a collaborative effort to identify connections between indepth case studies realized by different coauthors. The limitation posed by different methodologies, time frames, and research focus was compensated by the opportunity to combine a rich data set that covered several sites. As a result, this heterodox approach revealed important emerging properties that might not have been apparent when individual communities are studied. By linking the dots between the cases, the regional scale of tabuleiro management could be visualized. This analysis suggests that collaboration among researchers carried out in similar areas may help show how community-based processes contribute to larger scale regional processes.

Communities where turtle nesting sites emerge are seen as privileged areas; they have been granted a "premium" resource, which requires special attention and care. The persistence of collective efforts to protect a resource with high ecological risks and monitoring costs, and virtually no material benefits challenges usual conceptions of motivations, performance, and boundaries in the CBNRMs literature.

Motivation to participate in the management of turtle nesting sites involves a combination of material, social, and symbolic values. However, motivations are dynamic and may change over time. The management of the tabuleiro in ISM was initially the product of material motivations, and evolved into a conservation project led by a local leader who was fully supported by community residents. Nonmaterial values for conserving tabuleiros were rewarded by material gains from managing local fisheries. Consequently, taking advantage of these experiences is more challenging in communities where these synergies are missing. However, despite the challenges, communities were still motivated to engage in this collective endeavor, which leads to our second point.

Performance measured by outcomes at the managed site may mask important cross-border effects. Community-based natural resource management experiences trigger knowledge development, changes in values, and social learning, which can spill over into other initiatives in the community or beyond. In the case of the tabuleiros, whose dynamics are strongly influenced by regional ecological processes, malfunction or collapse of a management system may not imply poor performance; on the contrary, it may create opportunity to build intercommunity partnerships and develop creative strategies to cope with changes at the regional level, which leads to our third point.

Well-defined boundaries - social, institutional, and ecologicalare limited for understanding the emergence, performance, and decline of the community-based management of turtle nesting sites in the Amazon. This may be the case for other CBNRMs in complex ecosystems such as wetlands, where landscapes change continually and resource units are mobile and seasonal. In such social-ecological systems, "managed systems" and "community" as the units of analysis overlook relevant connections at the community level (such as the interplay between the lake management system and turtle nesting systems) as well as between communities (multiple turtle nesting sites).

In sum, in dynamic environments, a multidimensional approach to CBNRM may be necessary to reveal other forms of agency developed through horizontal connections between communities. Scaling up from local initiatives to examine connections between communities and exploring material and nonmaterial goals are critical to understanding the management of turtle nesting sites in the lower Amazon. We believe that research on similar socialecological systems can benefit from this analytical perspective. By combining multiple spatial, social, and value dimensions, the emergence and performance of these local institutions can be better evaluated and understood.

${ }^{[1]}$ Coordinated by the Federal University of Pará and the local NGO Institute for Amazon Environmental Research as part of a long-term involvement in development of natural resources and landscape management in the lower Amazon floodplain. The main objective was to consolidate lake fisheries management and disseminate the experiences, practices, and skills accumulated on the lake fisheries (McGrath et al. 1993, 2008, de Castro 2012), in particular, to include in the local management initiative of the pirarucu, two other aquatic wildlife resources: river turtles and caimans.

${ }^{[2]}$ This historical account was based mainly on several interviews with the main leader of the tabuleiro management in ISM.

[3] Although annual nest counts were not undertaken, the description of fast growth in turtle nesting in these sites is a common phenomenon which has been observed in other communities (with the exception of unusually low or high water seasons). 
${ }^{[4]}$ Name has been changed to ensure anonymity.

${ }^{[5]}$ Personal observation and interviews revealed that the apparent decline in numbers of nests in some years is a reflection of reduced monitoring (counting effort) rather than an actual decline in the number of females nesting in each area. During nesting seasons, beaches must be patrolled on a daily basis in order to detect fresh tracks of female turtles that lead to the newly built nests from the previous night. Inconsistent support of patrollers led to variation in counting effort across different years.

${ }^{[6]}$ A few initiatives were carried out in partnership with IBAMA. They exchanged 150 tracajá hatchlings from the community with 150 tartaruga hatchlings from a nesting area on the Tapajós River. A demarcation sign for the protected area was provided by IBAMA in 2004.

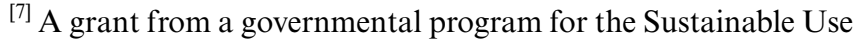
of Natural Resources in the whitewater floodplains of the Amazon basin (Provárzea), and grant from the World Wildlife Fund for community management initiatives, including turtle nesting areas and reforestation.

${ }^{[8]}$ The project involved residents of the neighboring communities of ISM and AGP who agreed to monitor their respective turtle nesting sites.

Responses to this article can be read online at: http://www.ecologyandsociety.org/issues/responses. php/10254

\section{Acknowledgments:}

The Brazilian and Dutch agencies CAPES and NUFFIC, respectively, provided support for the academic cooperation between the University of Pará and the University of Amsterdam. CAPES also provided the postdoc fellowship to JCBP (Process 3460-14-2). We thank the local communities that allowed the study and gave strong support for all the authors during the long and repeated fieldwork activities. We also thank the CEDLA and UFPA staff for their support, and the anonymous reviewers for their useful comments and suggestions.

\section{LITERATURE CITED}

Alves, R. R. N., and I.L. Rosa. 2007. Zootherapeutic practices among fishing communities in north and northeast Brazil: a comparison. Journal of Ethnopharmacology 11:82-103. http://dx. doi.org/10.1016/j.jep.2006.10.033

Alves, R. R. N., K. S. Vieira, G. G. Santana, W. L. S. Vieira, W. O. Almeida, W. M. S. Souto, P. F. G. P. Montenegro, and J. C. B. Pezzuti. 2011. A review on human attitudes towards reptiles in Brazil. Environmental Monitoring and Assessment 2011:6877-6901.

Barboza, R. S. L. 2012. Etnoecologia, pesca, práticas e saberes no manejo comunitário de quelônios aquáticos na várzea do Baixo Amazonas. Universidade Federal do Pará.

Bates, H. W. 1892. The naturalist on the river Amazon. Murray, London, UK.

Berkes, F. 2004. Rethinking community-based conservation. Conservation Biology 18(3):621-630. http://dx.doi.org/10.1111/ j.1523-1739.2004.00077.x
Berkes, F. 2006. From community-based resource management to complex systems: the scale issue and marine commons. Ecology and Society 11(1):45. http://dx.doi.org/10.5751/ES-01431-110145

Berkes, F., and C. Folke, editors. 1998. Linking social and ecological systems: management practices and social mechanisms for building resilience. Cambridge University Press, New York, USA.

Berkes, F., C. Folke, and J. Colding. 2000. Linking social and ecological systems: management practices and social mechanisms for building resilience. Cambridge University Press.

Bodin, Ö., and B. I. Crona. 2008. Management of natural resources at the community level: exploring the role of social capital and leadership in a rural fishing community. World Development 36(12):2763-2779. http://dx.doi.org/10.1016/j. worlddev.2007.12.002

Camillo, C. S., O. M. Santos, I. S. Sousa, and H. L. Queiroz. 2012. Community-based freshwater turtle conservation in Middle Solimões River, AM, Brazil. UAKARI 8(1):33-44.

Carvajal, G. 1543. Relación del nuevo descubrimiento del famoso Rio Grande de las Amazonas. Fondo de Cultura Econômica, primera edición de 1955, México.

Cash, D. W., W. Adger, F. Berkes, P. Garden, P. Lebel, P. Ollsson, L. Pritchard, and O. Young. 2006. Scale and cross-scale dynamics: governance and information in a multilevel world. Ecology and Society 11(2):8. http://dx.doi.org/10.5751/ES-01759-110208

Castello, L., J. P. Viana, G. Watkins, M. Pinedo-Vasquez, and V. A. Luzadis. 2009. Lessons from integrating fishers of Arapaima in small-scale fisheries management at the Mamirauá Reserve, Amazon. Environmental Management 43(2):197-209. http://dx. doi.org/10.1007/s00267-008-9220-5

Chandrakanth, M. G., M. G. Bhat, and M. Accavva. 2004. Socioeconomic changes and sacred groves in South India: protecting a community-based resource management institution. Natural Resources Forum 28(2):102-111). http://dx.doi.org/10.1111/ j.1477-8947.2004.00077.x

Child, B., and G. Barnes. 2010. The conceptual evolution and practice of community-based natural resource management in southern Africa: past, present and future. Environmental Conservation 37(3):283-295. http://dx.doi.org/10.1017/ S0376892910000512

Cleaver, F. 2002. Reinventing institutions: bricolage and the social embeddedness of natural resource management. European Journal of Development Research 14(2):11-30.

Cox, M., G. Arnold, and T. S. Villamayor. 2010. A review of design principles for community-based natural resource management. Ecology and Society 15(4):38.

de Castro, F. 2000. Fishing accords: the political ecology of fishing intensification in the Amazon. Dissertation. Indiana University, Bloomington, Indiana, USA.

de Castro, F. 2012. Between cooperation and conflict: the implementation of agro-extractive settlements in the lower Amazon floodplain. Pages 213-234 in E. S. Brondizio and E. F. Moran, editors. Human-environment interactions: current and 
future directions. Springer, Dordrecht, Netherlands. http://dx.doi. org/10.1007/978-94-007-4780-7_9

de Castro, F., and D. G. McGrath. 2003. Moving toward sustainability in the local management of floodplain lake fisheries in the Brazilian Amazon. Human Organization 62(2):123-133. http://dx.doi.org/10.17730/humo.62.2.9bkh58xeekj6bg0m

Delgado-Serrano, M., J. Mistry, B. Matzdorf, and G. Leclerc. 2017. Community-based management of environmental challenges in Latin America and the Caribbean. Ecology and Society 22(1):4. http://dx.doi.org/10.5751/ES-08924-220104

Denevan, W. M. 1992. The pristine myth: the landscape of the Americas in 1492. Annals of the Association of American Geographers 82(3):369-385.

Fachín-Terán, A., R. C. E. Vogt, and J. B. Thorbjarnarson. 2003. Patterns of use and hunting of turtles in the Mamirauá Sustainable Development Reserve, Amazonas, Brazil. Pages 362-377 in K. M. Silvius, R. Bodmer, and J. M. V. Fragoso, editors. People in nature: wildlife conservation in South and Central America. Columbia University Press, New York, USA.

Folke, C., T. Hahn, P. Olsson, and J. Norberg. 2005. Adaptive governance of social-ecological systems. Annual Review of Environment and Resources 30(1):441-473. http://dx.doi. org/10.1146/annurev.energy.30.050504.144511

Gadgil, M., and V. D. Vartak. 1976. The sacred groves of Western Ghats in India. Economic Botany 30(2):152-160. http://dx.doi. org/10.1007/BF02862961

Goulding, M., N. J. H. Smith, and D. J. Hahar. 1996. Floods of fortune - ecology and economy along the Amazon. Columbia University Press, New York, USA.

Hames, R. 2007. The ecologically noble savage debate. Annual Review of Anthropology36(1):177-190. http://dx.doi.org/10.1146/ annurev.anthro.35.081705.123321

Irion, G. 1984. Sedimentation and sediments of Amazonian rivers and evolution of the Amazon landscape since Pliocene times. Pages 201-2014 in S. Harald, editor. The Amazon: limnology and landscape ecology of a mighty tropical river and its basin. Dr. W. Junk Publishers, Dordrecht, Netherlands. http://dx.doi. org/10.1007/978-94-009-6542-3 7

Johns, A. D. 1987. Continuing problems for Amazon river turtles. Oryx 21(1):25-28. http://dx.doi.org/10.1017/S0030605300020445

Junk, W. J. 1997. General aspects of floodplain ecology with special reference to Amazonian floodplains. Pages 3-20 in W. J. Junk, editor. The central-Amazonian floodplain: ecology of a pulsing system. Springer-Verlag, New York, USA. http://dx.doi. org/10.1007/978-3-662-03416-3 1

McGrath, D. G., A. Cardoso, O. T. Almeida, and J. Pezzuti. 2008. Constructing a policy and institutional framework for an ecosystem-based approach to managing the lower Amazon floodplain. Environment, Development and Sustainability 10 (5):677-695. http://dx.doi.org/10.1007/s10668-008-9154-3

McGrath, D. G., F. de Castro, C. Futemma, B. D. de Amaral, and J. Calabria. 1993. Fisheries and the evolution of resource management on the lower Amazon floodplain. Human Ecology 21(2):167-195. http://dx.doi.org/10.1007/BF00889358
Mittermeier, R. A. 1975. A turtle in every pot - a valuable South American resource going to waste. Animal Kingdom (AprilMay):9-14.

Murrieta, R. S. S. 1998. O dilema do papa-chibé: consumo alimentar, nutrição e práticas de intervenção na Ilha de Ituqui, baixo Amazonas, Pará. Revista de Antropologia 41(1):97-150. http://dx.doi.org/10.1590/S0034-77011998000100004

Netting, R. M. 1976. What alpine peasants have in common: observations on communal tenure in a Swiss village. Human Ecology 4(2):135-146. http://dx.doi.org/10.1007/BF01531217

Ormsby, A. A., and S. A. Bhagwat. 2010. Sacred forests of India: a strong tradition of community-based natural resource management. Environmental Conservation 37(3):320-326. http:// dx.doi.org/10.1017/S0376892910000561

Ostrom, E. 1990. Governing the commons: the evolution of institutions for collective action. Cambridge University Press, Cambridge.

Ostrom, E., J. Burger, C. B. Field, R. B. Norgaard, and D. Policanky. 1999. Revisiting the commons: local lessons, global challenges. Science 284(5412):278-282. http://dx.doi.org/10.1126/ science. 284.5412 .278

Pereira, N. 1954. A tartaruga verdadeira do Amazonas. Ministério da Agricultura - Divisão de Caça e Pesca. Reedição. Rio de Janeiro, Brazil.

Pezzuti, J. C. B., J. P. Lima, D. F. da Silva, and A. Begossi. 2010. Uses and taboos of turtles and tortoises along Rio Negro, Amazon Basin. Journal of Ethnobiology 30(1):153-168. http://dx. doi.org/10.2993/0278-0771-30.1.153

Pezzuti, J. C. B., and R. C. Vogt. 1999. Nesting ecology of Podocnemis sextuberculata (Testudines, Pelomedusidae) in the Japurá River, Amazonas, Brazil. Chelonian Conservation Biology 3:419-424.

Pignati, M. T., L. F. Fernandes, S. Miorando, P. D. Ferreira, and J. C. B. Pezzuti. 2013. Nesting site and hatching success of Podocnemis unifilis (Testudines: Podocnemididae) in a floodplain area in lower Amazon River, Pará, Brazil. Copeia 8(3):175-185.

Rebêlo, G., and J. Pezzuti. 2000. Percepções sobre o consumo de quelônios na Amazônia: sustentabilidade e alternativas ao manejo atual. Ambiente \& Sociedade 3(6-7):1-21. http://dx.doi. org/10.1590/S1414-753X2000000100005

Redford, K. H., and A. M. Stearman. 1993. Forest-dwelling native Amazonians and the conservation of biodiversity: interests in common or in collision? Conservation Biology 7(2):248-255. http://dx.doi.org/10.1046/j.1523-1739.1993.07020248.x

Reichel-Dolmatoff, G. 1976. Cosmology as ecological analysis: a view from the rain forest. Man 11(3):307-318. http://dx.doi. $\underline{\text { org } / 10.2307 / 2800273}$

Romagnoli, F. C. 2016. O olhar do ribeirinho para a fauna aquática amazônica. Dissertation. Centre for Advanced Amazon Studies, University of Pará, Belém.

Roosevelt, A. C., R. A. Housley, M. I. Da Silveira, S. Maranca, and R. Johnson. 1991. Eighth millennium pottery from a prehistoric shell midden in the Brazilian Amazon. Science 254 (5038):1621-1624. http://dx.doi.org/10.1126/science.254.5038.1621 
Ruiz-Mallén, I., C. Schunko, E. Corbera, M. Rös, and V. ReyesGarcía. 2015. Meanings, drivers, and motivations for communitybased conservation in Latin America. Ecology and Society 20 (3):33. http://dx.doi.org/10.5751/ES-07733-200333

Sattler, C., B. Schröter, A. Meyer, G. Giersch, C. Meyer, and B. Matzdorf. 2016. Multilevel governance in community-based environmental management: a case study comparison from Latin America. Ecology and Society 21(4):24. http://dx.doi.org/10.5751/ ES-08475-210424

Schlager, E., and E. Ostrom. 1992. Property-rights regimes and natural resources: a conceptual analysis. Land Economics 68:249-262. http://dx.doi.org/10.2307/3146375

Seixas, C. S., and B. Davy. 2008. Self-organization in integrated conservation and development initiatives. International Journal of the Commons 2(1):99-125. http://dx.doi.org/10.18352/ijc.24

Silva-Coutinho, J. M. 1868. Sur le tortues de L'Amazone. Bulletinde la Socie'te' Zoologique d'Aclimatation 2(Tome V).

Smith, N. J. H. 1974. Destructive exploitation of the South American river turtle. Yearbook of the Association of Pacific Coast Geographers 36(1974):85-102. http://dx.doi.org/10.1353/pcg.1974.0000 